\title{
LACK OF RESPONSE OF SUGARCANE TO APPLICATIONS OF PHOSPHORUS IN PUERTO RICO
}

\author{
J. A. BONNET, B. G. CAPÓ AND A. RIERA
}

\section{INTRODUCTION}

In the last decade, 1934-1944, sugarcane, the most important economic crop of Puerto Rico, has occupied an average of 303,678 acres. The peak of total production was reached with the 1941-1942 crop which amounted to $10,010,132$ tons of cane and yielded 1,147,589 tons of sugar. The Association of Sugar Producers of Puerto Rico reports that in 1941, from January to December, 141,000 tons of fertilizer raw materials were imported-80,000 tons ammonium sulphate, 36,000 tons superphosphate and 25,000 tons potash salts-from which about 80 per cent or 112,800 tons were used for sugarcane. The normal application for fall and spring plantings of sugarcane in Puerto Rico is six bags of 200 pounds each, per acre; and for ratoons, 4 bags per acre. Except for certain sections of the arid region of the South coast of the Island where ammonium sulphate is applied only, a complete fertilizer is used as a general practice. From July 1941 to June 1942, both inclusive, 92,975 tons of complete fertilizers (5) were applied to sugarcane in Puerto Rico. The available phosphoric acid in those fertilizers varied between four and ten per cent and added up to 5,658 tons $\mathrm{P}_{2} \mathrm{O}_{5}$. At the estimated price of $\$ 28.00$ per ton of superphosphate containing 20 per cent available phosphoric acid, the consumption of phosphate fertilizer for the $1941-42$ crop amounted to $\$ 792,120$. The investment in phosphorus for sugarcane for the last 24 years (1920-1944) is estimated to be around ten million dollars.

The official fertilizer formulae for sugarcane approved by the War Production Board for manufacture in 1944-45, on the basis of $\mathrm{NH}_{3}, \mathrm{P}_{2} \mathrm{O}_{5}$ and $\mathrm{K}_{2} \mathrm{O}$, are: $10-6-9,12-4-9,14-6-5,14-6-8,14-3-8,14-0-7,14-0-11$. The demand for the formulae containing no phosphorus, however, has been practically negligible.

It is of economic importance, therefore, to determine if the continuous addition of phosphorus to the fertilizer is necessary for the sugarcane crop. It is also of importance to know if the placement of the fertilizer has any effect upon the response of the cane plant to applications of phosphorus.

EXPERIMENTAL WORK

A number of field experiments has been conducted in the past few years in which the need of phosphorus applications to maintain or increase 
sugar yields has been under study. In these experiments, phosphoric acid fertilizers have been tried in different amounts, the rate of the phosphoric acid applications varying from zero to a maximum of four hundred $\mathrm{P}_{2} \mathrm{O}_{5}$ per acre. The actual rates of application as well as the mean cane yields obtained in these experiments are presented in tables 1 and 2 .

The experiments were performed with several sugarcane varieties and they were established in the following 14 soil types (4) representing 84,224 acres of the most important sugarcane producing soils: "Toa silty clay loam", "Toa silty clay", "Toa clay", "Coloso silt loam", "Coloso silty clay loam", "Coloso silty clay", "Aguirre clay", "Vayas clay", "Vega Baja silty clay", "Mercedita clay", "Mabí clay", "Moca loam", "Vega Alta clay loam" and "Cataño sandy loam". The description of the soil series to which these soil types belong is as follows:

Toa. Series of the well-drained soils of the river flood plains in the humid area, derived from materials washed from the limestone and tuffaceous hills. They are neutral or slightly acid in reaction and are high in bases and plant nutrients. They are friable, brown soils from the surface to a depth of below four feet. The productivity rating of the loam to clay types is 1, i.e., they are rated among the best soils.

Coloso. Series of the poorly drained soils of the river flood plains in the humid area, derived from neutral, fine textured materials of volcanic rocks and limestone. They are poorly drained associates of the "Toa" series. They are deep, stone free, highly fertile, neutral, and plastic. Most areas have a heavy texture, a high water table, a dark surface soil, and a mottledgray, bluish-gray, and rust-brown subsoil. The productivity of the heavy types is rated between 1 and 2 .

Aguirre. Series of the poorly drained soils of the river flood plains in the arid area, that occupy areas that are transitional in character between the soils of the well drained river flood plains or alluvial fans, and the poorly drained soils of the coastal lowlands. In a cultivated field, "Aguirre clay" has a 10 or 12 inch very dark, grayish-brown and gray plastic sticky clay that continues to a depth ranging from 30 to 36 inches. The upper part of the substratum is a mottled-gray, rust-brown, and yellowishbrown, medium plastic, wet silty clay, that in places contains some mediumsized gravel. At a depth ranging from 5 to 6 feet is the substratum of bluish-gray, plastic, sticky wet clay. This layer continues to considerable depths and has characteristics of estuarine deposits. Nearly all of the layers in the profile contain free lime; many areas contain salts, chiefly sodium carbonate, that limit crop production. Areas that contain less than 0.2 per cent of salts within the first four feet are used under irrigation for the production of sugarcane. It has a productivity rating of 2 . The 
TABLE 1

Percentage increases in cane yields obtained when phosphoric acid applications were made

\begin{tabular}{|c|c|c|c|c|c|c|c|c|}
\hline \multirow{2}{*}{$\begin{array}{l}\text { CROP } \\
\text { No. }\end{array}$} & \multirow{2}{*}{$\begin{array}{l}\text { SOIL TYPE AND } \\
\text { LOCATION }\end{array}$} & \multirow{2}{*}{ CANE VARIETY } & \multirow{2}{*}{$\begin{array}{l}\text { KIND OF CROP } \\
\text { AND YEAR }\end{array}$} & \multicolumn{3}{|c|}{$\begin{array}{c}\text { FERTILIZERS APPLIFD } \\
\text { PER ACRE }\end{array}$} & \multirow{2}{*}{$\begin{array}{c}\text { CANE } \\
\text { YIELDS } \\
\text { PER } \\
\text { ACRE }\end{array}$} & \multirow{2}{*}{\begin{tabular}{|} 
IN- \\
CREASE \\
IN \\
YIELD
\end{tabular}} \\
\hline & & & & $\mathrm{NH}_{3}$ & $\mathrm{P}_{2} \mathrm{O}_{5}$ & $\mathrm{~K}_{2} \mathrm{O}$ & & \\
\hline 1 & $\begin{array}{l}\text { Coloso silty clay, } \\
\text { Toa Baja }\end{array}$ & BH-10(12) & $\begin{array}{l}\text { Plant Cane } \\
1937-1939\end{array}$ & $\begin{array}{l}\text { cwts. } \\
4 \\
4\end{array}$ & $\begin{array}{l}\text { cwts. } \\
0 \\
4\end{array}$ & $\begin{array}{l}\text { covts. } \\
4 \\
4\end{array}$ & $\begin{array}{c}\text { tons } \\
69.3 \\
70.2\end{array}$ & $\begin{array}{r}\text { per cent } \\
1.3\end{array}$ \\
\hline 2 & " " " & $\mathrm{BH}-10$ (12) & $\begin{array}{l}\text { First Ratoon } \\
1939-40\end{array}$ & $\begin{array}{l}4 \\
4\end{array}$ & $\begin{array}{l}0 \\
4\end{array}$ & $\begin{array}{l}4 \\
4\end{array}$ & $\begin{array}{l}50.7 \\
46.7\end{array}$ & -7.9 \\
\hline 3 & " & $\mathrm{BH}-10(12)$ & $\begin{array}{l}\text { Second Ratoon } \\
1940-41\end{array}$ & $\begin{array}{l}4 \\
4\end{array}$ & $\begin{array}{l}0 \\
4\end{array}$ & $\begin{array}{l}4 \\
4\end{array}$ & $\begin{array}{l}37.6 \\
40.8\end{array}$ & 8.5 \\
\hline & & & $\begin{array}{l}\text { Average of } 3 \\
\text { crops }\end{array}$ & $\begin{array}{l}4 \\
4\end{array}$ & $\begin{array}{l}0 \\
4\end{array}$ & $\begin{array}{l}4 \\
4\end{array}$ & $\begin{array}{l}52.5 \\
52.6\end{array}$ & 0.0 \\
\hline 4 & $\begin{array}{l}\text { Coloso silt loam } \\
\text { Toa Baja }\end{array}$ & $\mathrm{BH}-10(12)$ & $\begin{array}{l}\text { Plant Cane } \\
1938-40\end{array}$ & $\begin{array}{l}4 \\
4\end{array}$ & $\begin{array}{l}0 \\
4\end{array}$ & $\begin{array}{l}4 \\
4\end{array}$ & $\begin{array}{l}68.4 \\
71.2\end{array}$ & 4.1 \\
\hline 5 & “ & $\mathrm{BH}-10(12)$ & $\begin{array}{l}\text { First Ratoon } \\
1940-41\end{array}$ & $\begin{array}{l}4 \\
4\end{array}$ & $\begin{array}{l}0 \\
4\end{array}$ & $\begin{array}{l}4 \\
4\end{array}$ & $\begin{array}{l}49.8 \\
46.9\end{array}$ & -5.8 \\
\hline & & & $\begin{array}{l}\text { Average of } 2 \\
\text { crops }\end{array}$ & $\begin{array}{l}4 \\
4\end{array}$ & $\begin{array}{l}0 \\
4\end{array}$ & $\begin{array}{l}4 \\
4\end{array}$ & $\begin{array}{l}59.1 \\
59.1\end{array}$ & 0.0 \\
\hline 6 & " & POJ-2878 & $\begin{array}{l}\text { Plant Cane } \\
1938-40\end{array}$ & $\begin{array}{l}4 \\
4\end{array}$ & $\begin{array}{l}0 \\
4\end{array}$ & $\begin{array}{l}4 \\
4\end{array}$ & $\begin{array}{l}65.3 \\
65.0\end{array}$ & -0.5 \\
\hline 7 & « & POJ-2878 & $\begin{array}{l}\text { First Ratoon } \\
1940-41\end{array}$ & $\begin{array}{l}4 \\
4\end{array}$ & $\begin{array}{l}0 \\
4\end{array}$ & $\begin{array}{l}4 \\
4\end{array}$ & $\begin{array}{l}62.4 \\
60.3\end{array}$ & -3.4 \\
\hline & & & $\begin{array}{l}\text { Average of } 2 \\
\text { crops }\end{array}$ & $\begin{array}{l}4 \\
4\end{array}$ & $\begin{array}{l}0 \\
4\end{array}$ & $\begin{array}{l}4 \\
4\end{array}$ & $\begin{array}{l}63.9 \\
62.7\end{array}$ & -1.9 \\
\hline 8 & " $" 6$ & M-28 & $\begin{array}{l}\text { Plant Cane } \\
1938-40\end{array}$ & $\begin{array}{l}4 \\
4\end{array}$ & $\begin{array}{l}0 \\
4\end{array}$ & $\begin{array}{l}4 \\
4\end{array}$ & $\begin{array}{l}66.7 \\
67.1\end{array}$ & 0.6 \\
\hline 9 & " $\quad 4$ & M-28 & $\begin{array}{l}\text { First Ratoon } \\
1940-41\end{array}$ & $\begin{array}{l}4 \\
4\end{array}$ & $\begin{array}{l}0 \\
4\end{array}$ & $\begin{array}{l}4 \\
4\end{array}$ & $\begin{array}{l}45.5 \\
41.6\end{array}$ & -8.6 \\
\hline & & & $\begin{array}{l}\text { Average of } 2 \\
\text { crops }\end{array}$ & $\begin{array}{l}4 \\
4\end{array}$ & $\mid \begin{array}{l}0 \\
4\end{array}$ & $\begin{array}{l}4 \\
4\end{array}$ & $\begin{array}{l}56.1 \\
54.4\end{array}$ & -3.0 \\
\hline 10 & "6 6 & $M-275$ & $\begin{array}{l}\text { Plant Cane } \\
1938-40\end{array}$ & $\begin{array}{l}4 \\
4\end{array}$ & $\begin{array}{l}0 \\
4\end{array}$ & $\begin{array}{l}4 \\
4\end{array}$ & $\begin{array}{l}67.2 \\
68.1\end{array}$ & 1.3 \\
\hline
\end{tabular}


TABLE 1-Continued

\begin{tabular}{|c|c|c|c|c|c|c|c|c|}
\hline \multirow{2}{*}{$\begin{array}{l}\text { CROP } \\
\text { No. }\end{array}$} & \multirow{2}{*}{$\begin{array}{l}\text { SOIL TYPE AND } \\
\text { IOCATION }\end{array}$} & \multirow[t]{2}{*}{ CANE VARIETY } & \multirow{2}{*}{$\begin{array}{l}\text { KIND OF CROP } \\
\text { AND YEAR }\end{array}$} & \multicolumn{3}{|c|}{$\begin{array}{c}\text { FERTILIZERS APPLIED } \\
\text { PER ACRE }\end{array}$} & \multirow{2}{*}{$\begin{array}{c}\text { CANE } \\
\text { YIEIDS } \\
\text { PER } \\
\text { ACRE }\end{array}$} & \multirow{2}{*}{$\begin{array}{c}\text { IN- } \\
\text { CREASE } \\
\text { IN } \\
\text { YIELD }\end{array}$} \\
\hline & & & & $\mathrm{NH}_{3}$ & $\mathrm{P}_{2} \mathrm{O}_{5}$ & $\mathrm{~K}_{2} \mathrm{O}$ & & \\
\hline 11 & $\begin{array}{l}\text { Coloso silt loam } \\
\text { Toa Baja }\end{array}$ & M-275 & $\begin{array}{l}\text { First Ratoon } \\
1940-41 \\
\text { Average of } 2 \\
\text { crops }\end{array}$ & $\begin{array}{l}\text { cwis. } \\
4 \\
4 \\
4 \\
4\end{array}$ & $\begin{array}{l}\text { cowts } \\
0 \\
4 \\
0 \\
4\end{array}$ & $\begin{array}{l}c w t s . \\
4 \\
4 \\
4 \\
4\end{array}$ & $\begin{array}{c}\text { tons } \\
58.4 \\
60.9 \\
62.8 \\
64.5\end{array}$ & $\begin{array}{r}\text { per cent } \\
4.3 \\
2.7\end{array}$ \\
\hline 12 & $\begin{array}{l}\text { Aguirre clay, } \\
\text { Salinas }\end{array}$ & BH-10(12) & $\begin{array}{l}\text { Plant Cane } \\
1940-42\end{array}$ & $\begin{array}{l}4.5 \\
4.5\end{array}$ & $\begin{array}{l}0 \\
3\end{array}$ & $\begin{array}{l}4 \\
4\end{array}$ & $\begin{array}{l}45.1 \\
41.5\end{array}$ & -8.0 \\
\hline 13 & “ & POJ-2878 & $\begin{array}{l}\text { Plant Cane } \\
1940-42\end{array}$ & $\begin{array}{l}4.5 \\
4.5\end{array}$ & $\begin{array}{l}0 \\
3\end{array}$ & $\begin{array}{l}4 \\
4\end{array}$ & $\begin{array}{l}42.8 \\
45.0\end{array}$ & 5.1 \\
\hline 14 & $\begin{array}{l}\text { Mabi clay, } \\
\text { Juncos }\end{array}$ & POJ-2878 & $\begin{array}{l}\text { Plant Cane } \\
1940-42\end{array}$ & $\begin{array}{l}4.5 \\
4.5\end{array}$ & $\begin{array}{l}0 \\
3\end{array}$ & $\begin{array}{l}4 \\
4\end{array}$ & $\begin{array}{l}75.4 \\
79.0\end{array}$ & 4.8 \\
\hline 15 & $\begin{array}{l}\text { Mercedita clay, } \\
\text { Ponce }\end{array}$ & $\mathrm{BH}-10(12)$ & $\begin{array}{l}\text { Plant Cane } \\
1940-42\end{array}$ & $\begin{array}{l}4.5 \\
4.5\end{array}$ & $\begin{array}{l}0 \\
3\end{array}$ & $\begin{array}{l}4 \\
4\end{array}$ & $\begin{array}{l}97.0 \\
95.2\end{array}$ & -1.9 \\
\hline 16 & " & POJ-2878 & $\begin{array}{l}\text { Plant Cane } \\
1940-42\end{array}$ & $\begin{array}{l}4.5 \\
4.5\end{array}$ & $\begin{array}{l}0 \\
3\end{array}$ & $\begin{array}{l}4 \\
4\end{array}$ & $\begin{array}{l}108.8 \\
102.1\end{array}$ & -6.2 \\
\hline 17 & $\begin{array}{l}\text { Toa silty clay, } \\
\text { Manatí }\end{array}$ & M-275 & $\begin{array}{l}\text { Plant Cane } \\
1941-43\end{array}$ & $\begin{array}{l}2.325 \\
2.325\end{array}$ & 5 & $\begin{array}{l}2.325 \\
2.325\end{array}$ & $\begin{array}{r}94.9 \\
105.0\end{array}$ & 10.6 \\
\hline 18 & $\begin{array}{c}\text { Toa silty clay } \\
\text { loam, Manatí }\end{array}$ & BH-10(12) & $\begin{array}{l}\text { Plant Cane } \\
1942-43\end{array}$ & $\begin{array}{l}3 \\
3\end{array}$ & $\begin{array}{l}0 \\
2\end{array}$ & $\begin{array}{l}3 \\
3\end{array}$ & $\begin{array}{l}74.2 \\
73.7\end{array}$ & -0.7 \\
\hline 19 & $\begin{array}{l}\text { Coloso silt loam, } \\
\text { Fajardo }\end{array}$ & BH-10(12) & $\begin{array}{l}\text { Plant Cane } \\
1937-39\end{array}$ & $\begin{array}{l}4 \\
4\end{array}$ & $\begin{array}{l}0 \\
4\end{array}$ & $\begin{array}{l}4 \\
4\end{array}$ & $\begin{array}{l}89.8 \\
82.0\end{array}$ & -8.7 \\
\hline 20 & “ & BH-10(12) & $\begin{array}{l}\text { First Ratoon } \\
1939-40 \\
\text { Average of } 2 \\
\text { crops }\end{array}$ & $\begin{array}{l}4 \\
4 \\
4 \\
4\end{array}$ & $\begin{array}{l}0 \\
4 \\
0 \\
4\end{array}$ & $\begin{array}{l}4 \\
4\end{array}$ & $\begin{array}{l}48.4 \\
53.9 \\
\\
69.1 \\
68.0\end{array}$ & $\begin{array}{r}11.4 \\
-1.6\end{array}$ \\
\hline 21 & $\begin{array}{l}\text { Moca loam, Toa } \\
\text { Baja }\end{array}$ & POJ-2878 & $\begin{array}{l}\text { Plant Cane } \\
1939-40\end{array}$ & $\begin{array}{l}3 \\
3\end{array}$ & $\begin{array}{l}0 \\
3\end{array}$ & $\begin{array}{l}3 \\
3\end{array}$ & $\begin{array}{l}40.4 \\
43.5\end{array}$ & 7.7 \\
\hline 22 & $\begin{array}{r}\text { Coloso silty clay } \\
\text { loam, Naguabo }\end{array}$ & BH-10(12) & $\begin{array}{l}\text { First Ratoon } \\
1937-39\end{array}$ & $\begin{array}{l}3 \\
3\end{array}$ & $\begin{array}{l}0 \\
3\end{array}$ & $\begin{array}{l}3 \\
3\end{array}$ & $\begin{array}{l}81.9 \\
79.9\end{array}$ & -2.4 \\
\hline 23 & $\begin{array}{rr}\text { Cataño sandy } \\
\text { loam, Añasco }\end{array}$ & POJ-2878 & $\begin{array}{l}\text { Plant Cane } \\
1937-38\end{array}$ & $\begin{array}{l}0.9 \\
0.0\end{array}$ & $\begin{array}{l}0 \\
0.9\end{array}$ & $\begin{array}{l}0.9 \\
0.9\end{array}$ & $\begin{array}{l}47.4 \\
49.9\end{array}$ & 5.3 \\
\hline 24 & $\begin{array}{l}\text { Toa clay, Hor- } \\
\text { migueros }\end{array}$ & POJ-2878 & $\begin{array}{l}\text { Plant Cane } \\
1937-38\end{array}$ & $\begin{array}{l}0.9 \\
0.9\end{array}$ & $\begin{array}{l}0 \\
0.9\end{array}$ & $\begin{array}{l}0.9 \\
0.9\end{array}$ & $\begin{array}{l}36.9 \\
37.4\end{array}$ & 1.4 \\
\hline
\end{tabular}


land is difficult to plow and cultivate because when wet it is plastic and sticky, and when dry it is hard and cloddy.

Vayas. Series that occupy the more poorly drained level areas along

TABLE 2

Percentage increases in cane yields obtained with increases in phosphoricacidapplications above the minimum $0.20 \mathrm{cwt} . \mathrm{P}_{2} \mathrm{O}_{5}$ per acre applications

\begin{tabular}{|c|c|c|c|c|c|c|c|c|}
\hline \multirow{2}{*}{\multicolumn{3}{|c|}{ TREATMENTS }} & \multirow{2}{*}{\multicolumn{2}{|c|}{$\begin{array}{l}\text { POJ-2878, VEGA ALTA } \\
\text { CLAY LOAM, RÍ } \\
\text { PIEDRAS, FIRST } \\
\text { RATOON, 12 MIONTHS. } \\
1943-44\end{array}$}} & \multicolumn{4}{|c|}{ BH-10(12), VAYAS CLAY, SANTA RITA } \\
\hline & & & & & \multicolumn{2}{|c|}{$\begin{array}{l}\text { First ratoon, } 12 \\
\text { months. } 1942-43\end{array}$} & \multicolumn{2}{|c|}{$\begin{array}{c}\text { New planting of plant } \\
\text { cane, } 10 \text { months. } \\
1943-44\end{array}$} \\
\hline $\mathrm{NH}_{3}$ & $\mathrm{P}_{2} \mathrm{O}_{5}$ & $\mathrm{~K}_{2} \mathrm{O}$ & Yield & $\begin{array}{l}\text { Per cent } \\
\text { increase }\end{array}$ & Yield & Increase & Yie d & Increase \\
\hline $\begin{array}{r}\text { cwt./A. } \\
1.25\end{array}$ & $\begin{array}{c}c u l . / A \text {. } \\
0.20\end{array}$ & $\begin{array}{c}c w t . / A \\
0.90\end{array}$ & $\begin{array}{c}\text { tons } / A \text {. } \\
39.9\end{array}$ & & $\begin{array}{c}\text { tons } / A \\
33.8\end{array}$ & $\%$ & $\begin{array}{c}\text { tons } / A . \\
24.4\end{array}$ & $\%$ \\
\hline 1.25 & 0.80 & 0.90 & 38.8 & -2.8 & 30.0 & -11.2 & 24.1 & -1.2 \\
\hline 1.25 & 0.20 & 1.80 & 37.0 & & 30.5 & & 22.5 & \\
\hline 1.25 & 0.80 & 1.80 & 39.1 & 5.7 & 29.9 & -2.0 & 23.3 & 3.6 \\
\hline 1.25 & 0.20 & 2.70 & 39.6 & & 27.0 & & 25.5 & \\
\hline 1.25 & 0.80 & 2.70 & 40.6 & 2.5 & 31.4 & 16.3 & 24.0 & -5.9 \\
\hline 2.00 & 0.20 & 0.90 & 36.9 & & 29.9 & & 21.0 & \\
\hline 2.00 & 0.80 & 0.90 & 37.0 & 0.3 & 32.5 & 8.7 & 25.3 & 20.5 \\
\hline 2.00 & 0.20 & 1.80 & 38.8 & & 29.3 & & 21.0 & \\
\hline 2.00 & 0.80 & 1.80 & 39.3 & 1.3 & 32.8 & 11.9 & 26.9 & 28.1 \\
\hline 2.00 & 0.20 & 2.70 & 38.0 & & 30.1 & & 23.1 & \\
\hline 2.00 & 0.80 & 2.70 & 37.9 & -0.3 & 29.1 & -3.3 & 26.9 & 16.5 \\
\hline 2.75 & 0.20 & 0.90 & 37.9 & & 32.3 & & 24.4 & \\
\hline 2.75 & 0.80 & 0.90 & 38.6 & 1.8 & 30.6 & -5.3 & 22.1 & -9.4 \\
\hline 2.75 & 0.20 & 1.80 & 41.3 & & 34.3 & & 26.6 & \\
\hline 2.75 & 0.80 & 1.80 & 37.1 & -10.2 & 27.5 & -19.8 & 20.5 & -22.9 \\
\hline 2.75 & 0.20 & 2.70 & 36.1 & & 32.8 & & 26.8 & \\
\hline 2.75 & 0.80 & 2.70 & 37.9 & 5.0 & 29.9 & -8.8 & 23.6 & -11.9 \\
\hline 3.50 & 0.20 & 0.90 & 37.9 & & 29.9 & & 23.5 & \\
\hline 3.50 & 0.80 & 0.90 & 34.6 & -8.7 & 33.3 & 11.4 & 28.1 & 19.6 \\
\hline 3.50 & 0.20 & 1.80 & 40.0 & & 29.5 & & 26.3 & \\
\hline 3.50 & 0.80 & 1.80 & 35.5 & -11.3 & 31.4 & 6.4 & 24.4 & -7.2 \\
\hline 3.50 & 0.20 & 2.70 & 37.6 & & 32.9 & & 26.5 & \\
\hline 3.50 & 0.80 & 2.70 & 38.5 & 2.4 & 30.3 & -7.9 & 27.5 & 3.8 \\
\hline \multirow{2}{*}{\multicolumn{3}{|c|}{ 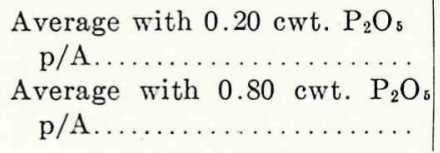 }} & 38.4 & & 31.0 & & 24.3 & \\
\hline & & & 37.9 & -1.3 & 30.7 & -1.0 & 24.7 & 1.6 \\
\hline
\end{tabular}

the river flood plains in the semiarid south coast section. "Vayas clay" has a brown or dark-brown clay in the surface and a mottled-gray or rustbrown and yellowish-brown layer beginning at a depth of about 30 inches and continuing to considerable depths. The average upper limit of the 
water table is about 30 inches. Nonalkali areas have a productivity rating of 1 . When wet it is plastic, and when it dries large cracks appear on the surface.

Vega Baja. Series of the poorly drained soils of the river flood plains in the humid region. They occupy bordering or intergrade areas between the alluvial soils and the coastal plain soils. They are slightly above normal overflow, but during exceptionally high water are flooded. The surface soil of the silty-clay type, to a depth of eight or ten inches, is acid, friable and granular. It has a light-brown or grayish-brown color. This layer changes abruptly to a plastic, medium compact, mottled, yellowishbrown, gray and red silty clay or clay subsoil, which continues to considerable depth, and becomes more definitely mottled and more acid with depth. Its productivity is rated between 2 and 3 .

Mercedita. Series of the inner plain soils in the arid region. The 12 inch surface soils of Mercedita clay consist of brown or dark-grayishbrown, granular calcareous clay, which is very plastic and waxy when wet. The subsoil is yellowish-brown or light olive-brown, medium compact, plastic calcareous clay, ranging from 10 to 15 inches in thickness. Below this layer is a very limy, friable, light-yellow silty material and soft limestone, which continues below a depth of 5 feet. Some areas contain harmful quantities of salts. Many areas are affected with lime chlorosis Its productivity is rated at 2 .

Mabi. Series of the inner plain soils in the humid region. "Mabí clay" occurs on long low gentle slopes, in close association with the "Múcara" and related brown, shallow soils of the uplands. It is derived from tuffaceous material, partly residual, and in part colluvial and alluvial. It has a grayish-brown, neutral, plastic heavy, clay surface soil, about eight or ten inches thick, which has good tilth when properly plowed and cultivated. The subsoil is a yellowish-brown, plastic sticky, neutral, heavy clay, streaked with rust-brown and gray material. This layer gradually changes, at a depth ranging from 30 to 40 inches, to friable brown and yellowish-brown silty clay loam that crumbles readily between the fingers. The material grades into desintegrated tuffaceous rock material at a depth ranging from four to 12 feet. Small fine white specks of the rock material occur in all layers. Its productivity is rated at 3.

Moca. Series of the inner plain soils in the humid area. "Moca loam" occurs on low sloping areas near the limestone hills. It has eight or teninch, acid, brown or dark-brown friable loam, which abruptly changes to heavy plastic, sticky, acid silty clay, or clay that is mottled red, gray, and brown. This layer continues downward for many feet. All layers contain a few rounded pieces of gravel or small rocks. Its productivity is rated at 6 .

Vega Alta. Series of the friable soils of the coastal plains in the humid 
region. "Vega Alta clay loam" has a friable, brown or light-brownishgray, acid surface, about eight inches thick, underlain by a reddish-brown, heavy, slightly plastic clay layer about 10 or 12 inches thick. This layer rests on more compact, mottled, brown, red, and gray clay, which continues to great depths before limestone is reached. Its productivity is rated at 5 .

Cataño. Series belonging to the soils of the coastal lowlands in the humid region. It occurs as a narrow strip paralleling the sea, a short distance inland. It has a 10 or 12 inch surface soil of grayish-brown or dark-grayish-brown, loose noncoherent loamy sand, alkaline in reaction. This layer is underlain by a lighter colored and lighter textured calcareous subsoil about two feet thick. The substratum, to a depth ranging from 10 to 15 feet, is loose, friable sand. Its productivity is rated at 6 .

The mean contents of phosphoric acid available in $1 \%$ citric acid, for various samples of soil types corresponding to the above soil series have been reported elsewhere (2.3) and are as follows:

\begin{tabular}{|c|c|c|}
\hline SOIL SERIES & SAMPLES ANALYZED & AVAILABLE $\mathrm{P}_{2} \mathrm{O}_{5}$ \\
\hline 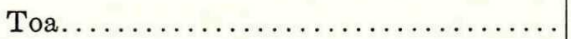 & 21 & .012 \\
\hline 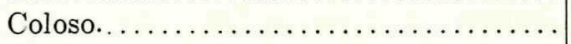 & 18 & .015 \\
\hline Aguirre $\ldots \ldots \ldots \ldots \ldots \ldots \ldots \ldots$ & 1 & .041 \\
\hline 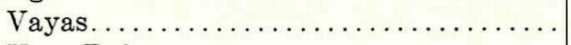 & 1 & .072 \\
\hline Vega Baja.................... & 4 & .013 \\
\hline 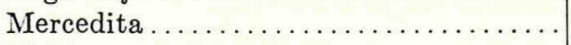 & 1 & .001 \\
\hline Mabi $\ldots \ldots \ldots \ldots \ldots \ldots \ldots \ldots$ & 11 & .005 \\
\hline Moca........................ & 3 & .003 \\
\hline Vega Alta $\ldots \ldots \ldots \ldots \ldots \ldots \ldots \ldots \ldots$ & 5 & .008 \\
\hline 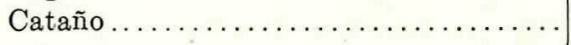 & 8 & .017 \\
\hline
\end{tabular}

The mean contents of total phosphoric acid of 7 samples of the Toa series and of 6 samples of the Coloso series were found (2) to be .113 and .154 per cent, respectively.

In general, the soil series of the arid region of Puerto Rico (3) contain about twice as much available phosphoric acid, soluble in $1 \%$ citric acid, than the soil series of the humid region. The mean difference is significant at the $1 \%$ point. The figures are as follows:

\begin{tabular}{c|c|c}
\hline \multicolumn{3}{c}{ PER CENT AVAILABLE P2OS IN SOIL SERIES OF } \\
\hline Humid Area & Arid Area & Mean Difference \\
\hline $.0079 \pm .0007$ & $.0173 \pm .0030$ & $.0094 \pm .002$ \\
\hline
\end{tabular}

Highly significant. 


\section{EXPERIMENTAL RESULTS}

Table 1 shows the yields of cane, in tons per acre, obtained in twentyfour crops of various sugarcane field experiments, both without and with a heavy application of phosphoric acid. Heavy applications of nitrogen and potash were added in all cases to insure the maximum possible responses from the phosphoric acid applications.

The first eighteen crops are from experiments performed in cooperation between the Soils and Agronomy Departments of the Agricultural Experiment Station of the University of Puerto Rico. Crops number 19 and 20 belong to an experiment carried out by Mr. Juan E. Veve, while at the Central Fajardo Experiment Station; crop no. 21 is from an experiment performed by Mr. Fernando Chardón at Central Constancia; crop no. 22 is from an experiment carried out by Mr. H. A. Nadler, Jr. of Eastern Sugar Associates; and crops nos. 23 and 24 were reported (1) by the Puerto Rico (Mayaguez) Agricultural Experiment Station.

Table 2 presents data relative to three crops of two long-time sugarcane field tests which are being performed by the Soils Department of the Agricultural Experiment Station of the University of Puerto Rico at Río Piedras and Ensenada.

The mean cane yield differences obtained with the varjous phosphoric acid applications in each of the experiments described in tables 1 and 2 were not statistically significant. This indicates that the sugarcane yields were not affected by the phosphoric acid applications, even in the case of crop number 3, which was the third crop in succession in which a heavy application of phosphoric acid was tested against no addition of this substance. That is, the phosphoric acid which this soil contained at the beginning of this test sufficed at least for maximum cane yield production of a plant cane and two ratoon crops. Similar statements may be made for the two consecutive crops, number 4 to 11 and 19 to 20 .

The lack of response of the sugarcane crop to the phosphoric acid applications in these experiments may have been due to one of two reasons:

1. The soils were in condition to supply the crops with enough phosphoric acid as to render unnecessary and superfluous any further applications of the substance.

2. The phosphoric acid, applied as superphosphate on top of the soil in some of the experiments described in table 1, was not able to penetrate to the root zone and did not exert its possible beneficial action on the crop.

If the first of the two reasons advanced above is applicable, then it must be admitted that sugarcane behaves differently from other crops such as native red beans, eggplant, corn, cucumbers, and sudan grass, all of which have responded markedly to phosphoric acid applications in several ex- 
periments performed on soil types similar to those in which the sugarcane has not responded to those applications. The long-time field experiments established at Río Piedras and Ensenada will be continued for a long number of years to determine how long will the minimum 20 pounds $\mathrm{P}_{2} \mathrm{O}_{5}$ per acre under test be able to maintain crop yields at the same levels as those obtained with the 80 pounds $\mathrm{P}_{2} \mathrm{O}_{5}$ per acre applications.

TABLE 3

Effect on the sugar cane yield of the method of applying the fertilizer

\begin{tabular}{|c|c|c|c|c|c|}
\hline \multirow{2}{*}{ NUMIBER } & \multirow{2}{*}{\begin{tabular}{|l|} 
TREATMENT \\
Method of applying the fertilizer, $\left(300 \mathrm{lbs} . \mathrm{NH}_{3}\right.$, \\
$100 \mathrm{lbs}, \mathrm{P}_{2} \mathrm{O}_{5}$ and $200 \mathrm{lbs} . \mathrm{K}_{2} \mathrm{O}$, per acre per crop $)$
\end{tabular}} & \multicolumn{4}{|c|}{$\begin{array}{c}\text { F-1017 ON "VEGA BAJA SIITY CLAY," Rí PIEDRAS } \\
\text { AUGUST } 1940 \text { TO MAY } 1944\end{array}$} \\
\hline & & Plant cane & $\begin{array}{c}\text { First } \\
\text { ratoon }\end{array}$ & $\begin{array}{l}\text { Second } \\
\text { Ratoon }\end{array}$ & $\begin{array}{l}\text { Total for } \\
3 \text { crops }\end{array}$ \\
\hline & & \multicolumn{4}{|c|}{ Tons cane per acre } \\
\hline 1 & $\begin{array}{l}\text { Phosphate for plant cane and two } \\
\text { ratoons mixed with the soil in the } \\
\text { furrow before planting; ammonia } \\
\text { and potash applied to each crop on } \\
\text { two } 3 \text {-inch deep furrows at the } \\
\text { sides of each row one month after } \\
\text { last replanting }\end{array}$ & 66.2 & 50.7 & 31.7 & 148.6 \\
\hline 2 & $\begin{array}{l}\text { Phosphate for plant cane and two } \\
\text { ratoons mixed with the soil in the } \\
\text { furrow before planting, ammonia } \\
\text { and potash on top soil for each } \\
\text { crop, one month after last re- } \\
\text { planting }\end{array}$ & 67.0 & 53.2 & 30.5 & 150.7 \\
\hline 3 & $\begin{array}{l}\text { Complete fertilizer applied to each } \\
\text { crop on } 3 \text {-inch deep furrows at the } \\
\text { sides of each row, one month after } \\
\text { last replanting }\end{array}$ & 69.6 & 53.0 & 31.5 & 154.1 \\
\hline 4 & $\begin{array}{l}\text { Check-Complete fertilizer applied } \\
\text { to each crop, on top of the soil, } \\
\text { one month after last replanting }\end{array}$ & 68.4 & 53.8 & 34.0 & 156.2 \\
\hline
\end{tabular}

To test the possibility of the second of the two reasons presented above, a fertilizer placement experiment was performed on a "Vega Baja silty clay" field very near to fields where heavy responses to the phosphoric acid applications had been observed with sudan grass and red beans.

In this experiment, different ways of applying the phosphoric acid were tested. The rates of application, yields obtained and other details are presented in table 3 .

The statistical analysis of the results obtained in this experiment indicated that none of the differences between the mean yields corresponding to the various ways of applying the fertilizer was significant. In this case, therefore, the second reason is not applicable. 
In view of the above results, it may be concluded for the time being that maximum sugar cane crops may be raised in the coastal plains of Puerto Rico without the application of any phosphoric acid for at least one crop cycle, that is, a plant cane and 2 ratoon crops. The results of the long-time tests under way at present will indicate in the near future whether this period may be lengthened and, if so, by how much.

The above results do not corroborate the statement which appeared in page 84 of the 1927-28 annual report of the Insular Experiment Station of Puerto Rico to the effect that an application of "phosphoric acid in excess of sixty pounds per "cuerda" (0.9712 acre) lowers the gain in yields of sugarcane". As the above data indicate, phosphoric acid applications, up to a maximum limit of four hundred pounds $\mathrm{P}_{2} \mathrm{O}_{5}$ per acre, have not affected, either for better or worse, the cane yields in the lowlands of Puerto Rico in experiments lasting a maximum of three and a half years. It is believed that the harmful effect of the heavy applications of phosphoric acid, was rather due to the fact that in the treatments involving such phosphoric acid applications the nitrogen level was lower than where smaller applications of phosphoric acid were made.

\section{SUMMARY}

1. The yearly investment in phosphoric acid as a fertilizer for sugarcane in Puerto Rico is about $\$ 800,000$.

2. Phosphoric acid applications have not exerted any effect, either beneficial or detrimental, on the cane yields of several successive sugarcane crops grown on the coastal plains of Puerto Rico.

3. Sugarcane may be raised for several years in the coastal plains of Puerto Rico without any phosphoric acid applications and with no appreciable reduction in sugarcane yields.

\section{LITERATURE CITED}

1. Anonymous. Report of the Puerto Rico Experiment Station (Mayaguez) for 1938, pp. 83-84.

2. Bonnet, J. A. Phosphoric acid and silica of Puerto Rico soils. Jour. Agr., 24 (4) : 143-150, Oct. 1940.

3. Bonnet, J. A. Chemical data of Puerto Rico soils. Correlation of data for humid and arid areas. Field response of crop to available phosphorus and potash in soils. Agr. Exp. Sta. Res. Bul. 1, 53 p., April 1941.

4. Roberts, R. C. and party. Soil Survey of Puerto Rico. U.S.D.A. Bur. Pl. Ind. in coop. with University of Puerto Rico, Agricultural Experiment Station. Ser. 1936 (8), 503 p., January 1942.

5. Villá-Mayo, R. Informe Anual del Laboratorio Químico para Abonos y Alimentos Concentrados para Animales Domésticos. Departamento de Agricultura y Comercio de Puerto Rico, 27 p., 1941-1942. 